\title{
CHROMATOGRAPHIC ANALYSIS, ANTIPROLIFERATIVE EFFECT AND GENOTOXICITY OF AQUEOUS EXTRACTS OF Citrus sinensis (L.) OSBECK ON THE Allium cepa L. TEST SYSTEM
}

\author{
ANÁLISE CROMATOGRÁFICA, EFEITO ANTIPROLIFERATIVO E \\ GENOTOXICIDADE DE EXTRATOS AQUOSOS DE Citrus sinensis (L.) OSBECK \\ SOBRE O SISTEMA TESTE DE Allium cepa $L$.
}

\section{Marília TEDESCO'; Andrielle Wouters KUHN²; Aline Augusti BOLIGON ${ }^{3}$; Haywood Dail LAUGHINGHOUSE IV ${ }^{4}$; Margareth Linde ATHAYDE ${ }^{5}$; Antonio Carlos Ferreira da SILVA ${ }^{5}$; Solange Bosio TEDESCO ${ }^{5}$}

1. Mestre em Agrobiologia, Universidade Federal de Santa Maria, Santa Maria, RS, Brasil; 2. Doutoranda em Agronomia, Universidade Federal de Santa Maria, Santa Maria, RS, Brasil; 3. Pós-doutoranda em Ciências Farmacêuticas, Universidade Federal de Santa Maria, Santa Maria, RS, Brasil; 4. PhD, The University Centre in Svalbard, Longyearbyen, Noruega; 5. Professor (a), Doutor (a), Universidade Federal de Santa Maria, Santa Maria, RS, Brasil. solatedesco@gmail.com

\begin{abstract}
The species Citrus sinensis (L.) Osbeck (orange) is used in folk medicine as an infusion (tea) for the treatment of nerve irritation, insomnia, spasms, whooping cough, flue, and gastrointestinal problems. The aim of this study was to evaluate the antiproliferative and genotoxic potential of aqueous extracts of $C$. sinensis testing by Allium cepa L., as well as to determine the components in the complex mixture (tea). Leaves from two populations of this species were used in the preparation of infusions at two concentrations: $6 \mathrm{~g} . \mathrm{L}^{-1}$ and $24 \mathrm{~g} . \mathrm{L}^{-1}$, besides using distilled water as a negative control and $9.6 \%$ glyphosate as a positive control. Six groups of four bulbs of $A$. cepa were used, each group corresponding to one of the treatments. The bulbs were rooted in distilled water and then transferred to the respective treatments where they remained for 24 hours (the bulbs of the negative control remained in distilled water). The rootlets were collected, fixated in ethanol-acetic acid (3:1) for 24 hours and stored in 70\% alcohol. 4,000 cells were analyzed per group of bulbs, and the calculated mitotic indices were submitted to statistical analysis using the $\chi^{2}$ test. The aqueous extracts of $C$. sinensis have as main components flavonoids and phenolic acids. The values of the mitotic index decreased with increasing concentration of the extracts relative to the control in water. The results indicated that the orange aqueous extracts in the studied concentrations in both populations have antiproliferative and genotoxic effects on the cell cycle of A. cepa.
\end{abstract}

KEYWORDS: Medicinal plant. Orange. Onion. Mitotic index. Mutagenic.

\section{INTRODUCTION}

Medicinal plants are highly used in popular medicine, and sometimes the only source of medication for local populations. However, their inadequate and uncontrolled use can cause more damage than benefits to human health (AMORIM et al., 2007; LANINI et al., 2009). Citrus sinensis (L.) Osbeck (family Rutaceae) is among one of the plants with medicinal potential.

The family Rutaceae contains close to 150 genera, distributed in the tropical and subtropical regions of the world. They are sub-shrub or arboreal plants with compound leaves, generally of alternate arrangement, without stipules, containing scented glands, frequently having spines (JOLY, 2002). The genus Citrus is the most important in the family, due to the large number of fruit-bearing species known by citriculturists and consumers worldwide. Plants in this genus are always large green shrubs or small trees, with $5-15 \mathrm{~m}$ high (ANWAR et al., 2008).
The species $C$. sinensis (orange) comes from South Asia and has adapted perfectly to Brazil, existing in all the national territory (CARIBÉ; CAMPOS, 1991). Besides the known and appreciated taste, it is also used of medicinal use; oil is extracted from the peel and tea can be made from the leaves (SCHULTZ, 1984).

The orange has calming and aromatic properties. Infusions of its leaves are indicated in cases of nerve irritations, insomnia, spasms, convulsive coughs (YARZA, 2001), colds and gastrointestinal problems (BARATA-SILVA et al., 2005).

The majority of medicinal plants are not sufficiently studied as to their cytotoxic/mutagenic actions, which can be monitored by the Allium cepa L. test system. The International Programme on Chemical Safety (IPCS, OMS) and the United Nations Environment Programm (UNEP) have validated this method of evaluating chromosomal alterations in A. cepa rootlets as an efficient test for analyzing and monitoring in situ the genotoxicity of 
environmental substances (CABRERA; RODRIGUEZ, 1999). Besides this, studies using this system together with mammals have been carried out, demonstrating that the results obtained are similar (TEIXEIRA et al., 2003; CAMPAROTO et al., 2002; VICENTINI et al., 2001).

Studies involving the genotoxicity of medicinal plants are extremely important, foreseeing that they can alert the population about possible and eventual damages caused to target organisms by substances present in the aqueous extracts, since these substances are many times also used in pharmaceutical formulations (FRESCURA, 2012).

Due to the intense use of medicinal plants, this study aimed to evaluate the genotoxic and antiproliferative effects of the aqueous extracts of $C$. sinensis leaves on the cell cycle of $A$. cepa, as well as determine the components of the complex mixture (aqueous extracts) by separation of substances through high performance liquid chromatography (HPLC).

\section{MATERIAL AND METHODS}

\section{Plant Collection}

The experiment was developed in the Laboratory of Plant Cytogenetics and Genotoxicity (LABCITOGEN) of the Universidade Federal de Santa Maria (UFSM), Santa Maria, RS, Brazil. The leaves of $C$. sinensis were collected in the municipalities of Santa Maria - RS (population 1) and Tupanciretã - RS (population 2). From each population a voucher specimen (exsicata) was deposited in the Herbarium SMDB (Santa Maria Departamento de Biologia) of the Universidade Federal de Santa Maria, under the registration number 13.962 (Population 1 - SM) and 13.963 (Population 2 - Tupã).

\section{Preparation of the Infusions}

Dry leaves of the two populations were weighed using a precision scale, placed in a beaker (1L), and distilled water was added at $100^{\circ} \mathrm{C}$, infused for 10 minutes. Afterwards, the infusions were filtered and cooled at room temperature. The aqueous extracts (teas) were prepared at two concentrations for each population: $6 \mathrm{~g} \cdot \mathrm{L}^{-1}$ and $24 \mathrm{~g} . \mathrm{L}^{-1}$, where $6 \mathrm{~g} . \mathrm{L}^{-1}$ is the common concentration used by the population for the preparation of medicinal teas.

\section{Biological Assay}

Six groups of four bulbs of A. cepa were used, each group corresponding to a treatment. The six groups of bulbs were placed to root in distilled water and after the roots emerged, each group was transferred to its respective treatment. The first group was used as a negative control, remaining in distilled water and the rest, respectively, were transferred to the following treatments: tea of $6 \mathrm{~g} . \mathrm{L}^{-1}$ (population 1 - SM), tea of $6 \mathrm{~g} . \mathrm{L}^{-1}$ (population 2 Tupã), tea of $24 \mathrm{~g} . \mathrm{L}^{-1}$ (population 1), tea of $24 \mathrm{~g} . \mathrm{L}^{-1}$ (population 2), and glyphosate (positive control), where they remained for 24 hours. The rootlets were then collected and fixed in ethanol:acetic acid (3:1) during 24 hours. After this period, the roots were maintained in alcohol $70 \%$ and conserved refrigerated $\left(4^{\circ} \mathrm{C}\right)$ until slide preparation.

\section{Effects of the infusions on the cell cycle of $A$. cepa}

Two slides per bulb of $A$. cepa of each treatment were prepared, using one rootled per bulb. For slide preparation, A. cepa rootlets were hydrolyzed in $\mathrm{HCl} 1 \mathrm{~N}$ for 5 minutes, washed in distilled water, and then stained using acetic orcein $2 \%$. The meristematic region of the rootlets was fragmented using a needle tool, and the slide placed on the material (GUERRA; SOUZA, 2002). The analysis of 1,000 cells per bulb was performed, totaling in 4,000 cells per treatment. The slides were analyzed using a light microscope at 400X, observing the cells in interphase and cell division (mitosis) to calculate the Mitotic Index (MI), as well as the occurrence of cell aberrations, such as the presence of bridges, laggard chromosomes, micronucleus, binucleous cells, amongst others.

\section{Chromatographic analysis of the complex mix by high performance liquid chromatography (HPLC-DAD)}

All the chemical reagents were of analitical degree. Methanol, acetic acid, gallic acid, chlorogenic acid, and caffeic acid were acquired from Merck (Darmstadt, Alemanha). Rutin and kaempferol were acquired from Sigma Chemical Co. (St. Louis, MO, EUA). High performance liquid chromotagraphy (HPLC-DAD) was carried out with a HPLC system (Shimadzu, Kyoto, Japan) and autoinjector Shimadzu (SIL-20A), equipped with alternative pumps (Shimadzu LC-20AT) connected to a degasifier (20A5 DGU) with an integrator (CBM 20A), detector of diode arranges (SPDM20A) and software (LC solution SP1 1.22).

Chromatographic analyses were undertaken in reverse phase under gradient conditions using a C18 column $(4.6 \mathrm{~mm} \times 150 \mathrm{~mm})$ filled with particles of $5 \mu \mathrm{m}$ wide, the mobile phase used was water containing $2 \%$ of acetic acid (A) and methanol (B), and the gradient of composition was: 5\% (B) during $2 \mathrm{~min}, 25 \%$ (B) to $10 \mathrm{~min}, 40,50,60,70$, and $80 \%$ 
(B) for each $10 \mathrm{~min}$, following the method decribed by Laghari et al. (2011) with few modifications. The infusions of $C$. sinensis were analyzed at a concentration of 24 and 6 g.L $\mathrm{L}^{-1}$. The flow used was $0.6 \mathrm{~mL} / \mathrm{min}$, injection volume of $50 \mu \mathrm{L}$, and the wavelength was $271 \mathrm{~nm}$ for gallic acid, $327 \mathrm{~nm}$ for caffeic and chlorogenic acids, and $365 \mathrm{~nm}$ for rutin and kaempferol. The samples and the mobile phase were filtered through a $0.45 \mu \mathrm{m}$ membrane filter (Millipore) and then degassed through ultrasound bath before use. The reference solutions were prepared in the mobile phase for HPLC at the concentrations of $0.050-250 \mathrm{mg} \cdot \mathrm{mL}^{-1}$ for rutin and kaempferol and $0.20-200 \mathrm{mg} \cdot \mathrm{mL}^{-1}$ for gallic, caffeic, and chlorogenic acids. The chromatographic peaks were confirmed by comparing their retentions times with the reference standards and DAD spectra (200 to $600 \mathrm{~nm})$. The calibration curve for gallic acid was: $\mathrm{Y}=13569 \mathrm{x}+$ 1344.9 ( $\mathrm{r}=0.9995)$; chlorogenic acid: $\mathrm{Y}=12573 \mathrm{x}+$ $1206.5(\mathrm{r}=0.9997)$, caffeic acid: $\mathrm{Y}=11872 \mathrm{x}+$ $1570.3(\mathrm{r}=0.9996)$, rutin: $\mathrm{Y}=15983 \mathrm{x}+1321.5(\mathrm{r}=$ 0.9998), and kaempferol: $\mathrm{Y}=16423 \mathrm{x}+1853.2(\mathrm{r}=$ 0.9998). All the chromatographic operations were undertaken at room temperature in triplicate.

\section{Statistical Analysis}

Table 1. Number of meristematic cells in different phases of the cell cycle of A. cepa submitted to different treatments.

\begin{tabular}{|c|c|c|c|c|c|c|}
\hline Treatment & Interphase & Prophase & Metaphase & Anaphase & Telophase & $\begin{array}{c}\text { Mitotic Index } \\
(\%)\end{array}$ \\
\hline $\begin{array}{l}\text { Negative } \\
\text { control }\end{array}$ & 3668 & 166 & 66 & 39 & 61 & $8,3^{\mathrm{a}}$ \\
\hline $\begin{array}{c}\text { Population } 1- \\
6 \mathrm{~g} . \mathrm{L}^{-1}\end{array}$ & 3895 & 50 & 18 & 10 & 27 & $2,62^{\mathrm{c}}$ \\
\hline $\begin{array}{l}\text { Population } 2- \\
6 \mathrm{~g} . \mathrm{L}^{-1}\end{array}$ & 3869 & 72 & 28 & 12 & 19 & $3,28^{\mathrm{b}}$ \\
\hline $\begin{array}{l}\text { Population } 1 \text { - } \\
24 \mathrm{~g} \cdot \mathrm{L}^{-1}\end{array}$ & 3944 & 38 & 10 & 2 & 6 & $1,4^{\mathrm{d}}$ \\
\hline $\begin{array}{l}\text { Population } 2- \\
24 \mathrm{~g} . \mathrm{L}^{-1}\end{array}$ & 3966 & 22 & 6 & 2 & 4 & $0,85^{\mathrm{e}}$ \\
\hline Positive control & 4000 & - & - & - & - & $0^{f}$ \\
\hline
\end{tabular}

Averages followed by the same letter do not differ significantly at the 5\% level, by the $\chi^{2}$ test.
The statistical analysis of mitotic index and chromosomal changes was performed using the $\chi^{2}$ test with a level of probability of $<0,05$ through the program BioEstat 5,3 (AYRES, 2007).

The statistical analysis regarding the chromatographic analysis was carried out using the Tukey test with $\mathrm{p}<0.05$.

\section{RESULTS AND DISCUSSION}

Sensitivity studies and the correlation of the A. сера biotest and other biotests are fundamental to precisely evaluate environmental risks, as well as extrapolate data to other organisms, including humans. The tests for detection of risks to human health are carried out using several test systems, including A. cepa (LEME et al., 2009).

The Table 1 shows the number of cells in interphase, the number of cells in the different phases of the A. cepa cell cycle treated with the aqueous extracts in two concentrations of two $C$. sinensis populations and the mitotic index values. The Table 2 illustrates the total number of cells in division, the alterations that occurred during mitotic cell division in the roots of $A$. сеpa, and the total number of cell aberrations. 
Table 2. Number of cells in division, number and types of cell aberrations, and total number of aberrant cells.

\begin{tabular}{|c|c|c|c|c|c|c|}
\hline \multirow[b]{2}{*}{ Treatment } & \multirow[b]{2}{*}{$\begin{array}{l}\text { Cells in } \\
\text { division }\end{array}$} & \multicolumn{4}{|c|}{ Cell aberrations } & \multirow[b]{2}{*}{$\begin{array}{c}\text { Total of } \\
\text { aberrant } \\
\text { cells }\end{array}$} \\
\hline & & Bridges & $\begin{array}{c}\text { Breakages and } \\
\text { laggard } \\
\text { chromosomes }\end{array}$ & $\begin{array}{l}\text { Binucleated } \\
\text { cells }\end{array}$ & $\begin{array}{c}\text { Micronucleate } \\
\text { d cells }\end{array}$ & \\
\hline $\begin{array}{l}\text { Negative } \\
\text { control }\end{array}$ & 332 & 1 & 2 & - & - & 3 \\
\hline $\begin{array}{c}\text { Population } 1- \\
6 \mathrm{~g} . \mathrm{L}^{-1}\end{array}$ & 105 & 2 & 1 & - & 79 & 82 \\
\hline $\begin{array}{c}\text { Population } 2- \\
6 \mathrm{~g} . \mathrm{L}^{-1}\end{array}$ & 131 & 2 & 2 & - & 67 & 71 \\
\hline $\begin{array}{c}\text { Population } 1- \\
24 \mathrm{~g} . \mathrm{L}^{-1}\end{array}$ & 56 & 1 & 3 & - & 149 & 153 \\
\hline $\begin{array}{c}\text { Population } 2- \\
24 \mathrm{~g} . \mathrm{L}^{-1}\end{array}$ & 34 & - & 2 & 1 & 188 & 191 \\
\hline Positive control & - & - & - & 4 & 299 & 303 \\
\hline
\end{tabular}

The results presented in Table 1 demonstrated values of the mitotic indices of $8.3 \%$ for the negative control (distilled water), $2.62 \%$ for the aqueous extract of $6 \mathrm{~g} . \mathrm{L}^{-1}$ (pop. 1), $3.28 \%$ for the aqueous extract of $6 \mathrm{~g} . \mathrm{L}^{-1}$ (pop. 2), $1.4 \%$ for the aqueous extract of $24 \mathrm{~g} . \mathrm{L}^{-1}$ (pop. 1 ), $0.85 \%$ for the aqueous extract of $24 \mathrm{~g} . \mathrm{L}^{-1}$ (pop. 2), and $0 \%$ for the positive control (glyphosate $9.6 \%$ ). These results indicate that there was a significant reduction in the mitotic index at $6 \mathrm{~g} . \mathrm{L}^{-1}$ of the aqueous extracts of the orange tree in both populations when compared with the negative control (pop. 1: $\chi^{2}=124,729$ e pop. 2: $\chi^{2}=92,620$ ). The decrease in the mitotic index was also significant when comparing the negative control with the concentration of $24 \mathrm{~g} . \mathrm{L}^{-1}$ of both populations (pop. 1: $\chi^{2}=206,337$ e pop. $2: \chi^{2}=$ 254,267). Furthermore, there was a significant difference between the mitotic index of the negative and positive controls $\left(\chi^{2}=346,375\right)$, being that in the positive control (glyphosate 9.6\%) the decrease in the mitotic index was total. The mitotic index values also differed significantly between populations 1 and 2 , both at $6 \mathrm{~g} \cdot \mathrm{L}^{-1}\left(\chi^{2}=2,951\right)$ and at $24 \mathrm{~g} . \mathrm{L}^{-1}\left(\chi^{2}=5,439\right)$. In both populations there was a significant decrease in the mitotic index with the increase in the concentration (pop. 1: $\chi^{2}=$ 15,219 and pop. $2: \chi^{2}=58,225$ ).

The evaluation of the effect of aqueous extracts of $C$. sinensis by the $A$. cepa test demonstrated that there was a significant inhibition of cell division at all analyzed concentrations examined in both populations, leading to a decrease in the values of the mitotic index (Table 1), which indicates the antiproliferative activity of the species. Similar studies that demonstrated the antiproliferative activity of plant species using the A. cepa test were reported by Knoll et al. (2006), where different populations of Pterocaulon polystachyum DC. were studied and a decrease in the mitotic index was observed with an increase in the concentrations of the aqueous extracts. Other authors have also verified the antiproliferative activity of medicinal species using the $A$. cepa test system, such as Fachinetto et al. (2007) studying Achyrocline satureioides (Lam.) DC, Dalla Nora et al. (2010) evaluating Mikania glomerata Sprengel, and Souza et al. (2010) analyzing Artemisia verlotorum Lam.

According to Fiskesjö (1994), even though plant metabolism is different, the A. cepa test 
system is an excellent parameter for cytotoxic analysis, besides the observation of chromosomal alterations in the cell cycle of $A$. cepa being used as an indicator to prevent people on consuming a product (VICENTINI et al., 2001).

The aqueous extracts of $C$. sinensis presented four types of cell aberrations (Table 2): micronucleated cells (Figure 1a), binucleated cells (Figure 1b), cells with bridges in anaphase (Figure 1c), and cells with breakages and laggard chromosomes (Figure 1d). In population 1, the number of cell aberrations observed in the cells of A. cepa differed from the control in both concentrations $\left(6 \mathrm{~g} \cdot \mathrm{L}^{-1}: \chi^{2}=72,659\right.$ and $24 \mathrm{~g} \cdot \mathrm{L}^{-1}: \chi^{2}=$ $141,520)$, as well as in population $2\left(6 \mathrm{~g} . \mathrm{L}^{-1}: \chi^{2}=\right.$ 61.918 e $\left.24 \mathrm{~g} . \mathrm{L}^{-1}: \chi^{2}=177.966\right)$. Besides this, with
TEDESCO, M. et al.

an increase of the concentrations, there was an increase in the cell aberrations with a significant difference in both populations (pop. 1: $\chi^{2}=20,840$ and pop. $2: \chi^{2}=53,230$ ). This demonstrates that the aqueous extracts of $C$. sinensis leaves at the analyzed concentrations present an elevated genotoxic potential. Fachinetto \& Tedesco (2009) used the $A$. серa test system to examine the genotoxicity of extracts of Baccharis trimera (Less.) DC and Baccharis articulata (Lam.) Pers. at different concentrations, attributing the genotoxic effect of these species to the chromosomal anomalies found in all the studied treatments, such as binucleated cells, micronuclei, and anaphasic bridges.

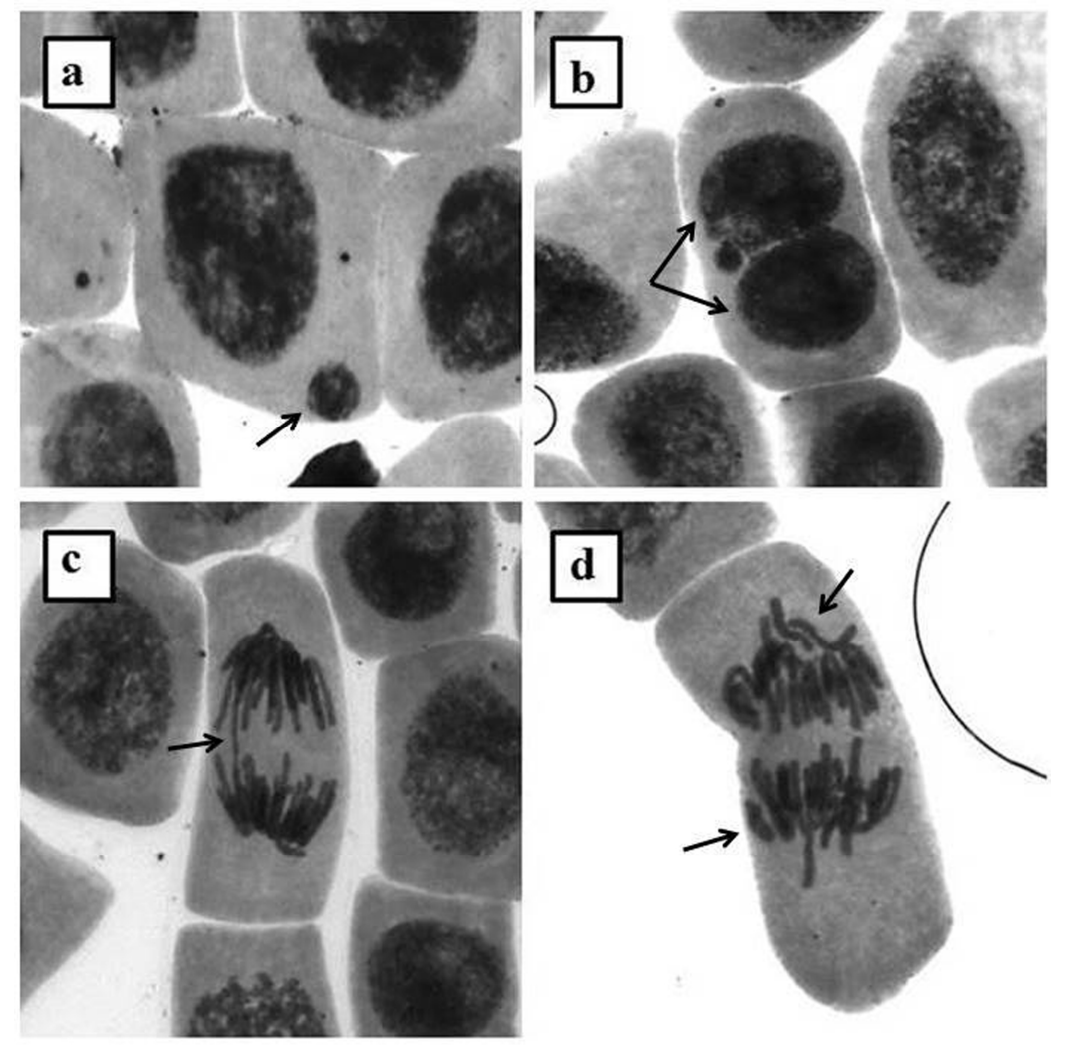

Figure 1. Cells of A. cepa submitted to the aqueous extracts of $C$. sinensis. a - arrow indicating micronucleus (cell treated with aqueous extract of $24 \mathrm{~g} . \mathrm{L}^{-1}$, population 2 ); $\mathrm{b}$ - arrow indicating binucleated cell (cell treated with glyphosate 9.6\%); c - arrow indicating anaphasic bridge (cell treated with aqueous extract of $6 \mathrm{~g} . \mathrm{L}^{-1}$, population 1$) ; \mathrm{d}-$ arrows indicating breakage and laggard chromosomes (cell treated with aqueous extract of $6 \mathrm{~g} \cdot \mathrm{L}^{-1}$, population 1 ).

The chromatograms of $C$. sinensis revealed the presence of gallic acid $\left(t_{R}=8.71\right.$ min; peak 1$)$, chlorogenic acid $\left(t_{R}=16.93\right.$ min; peak 2$)$, caffeic acid $\left(t_{R}=23.46\right.$; peak 3$)$, rutin $\left(t_{R}=37.51\right.$ min; peak 4 ), and kaempferol $\left(t_{R}=48.95\right.$ min; peak 5) (Figure 2 and Tables 3 and 4). The HPLC analysis revealed that flavonoids (rutin and kaempferol) and phenolic acids (gallic acid, caffeic acid, and chlorogenic acid) are the principal components of $C$. sinensis, which was corroborated by other researchers in independent studies on this species (KELEBEK et al., 2009). 


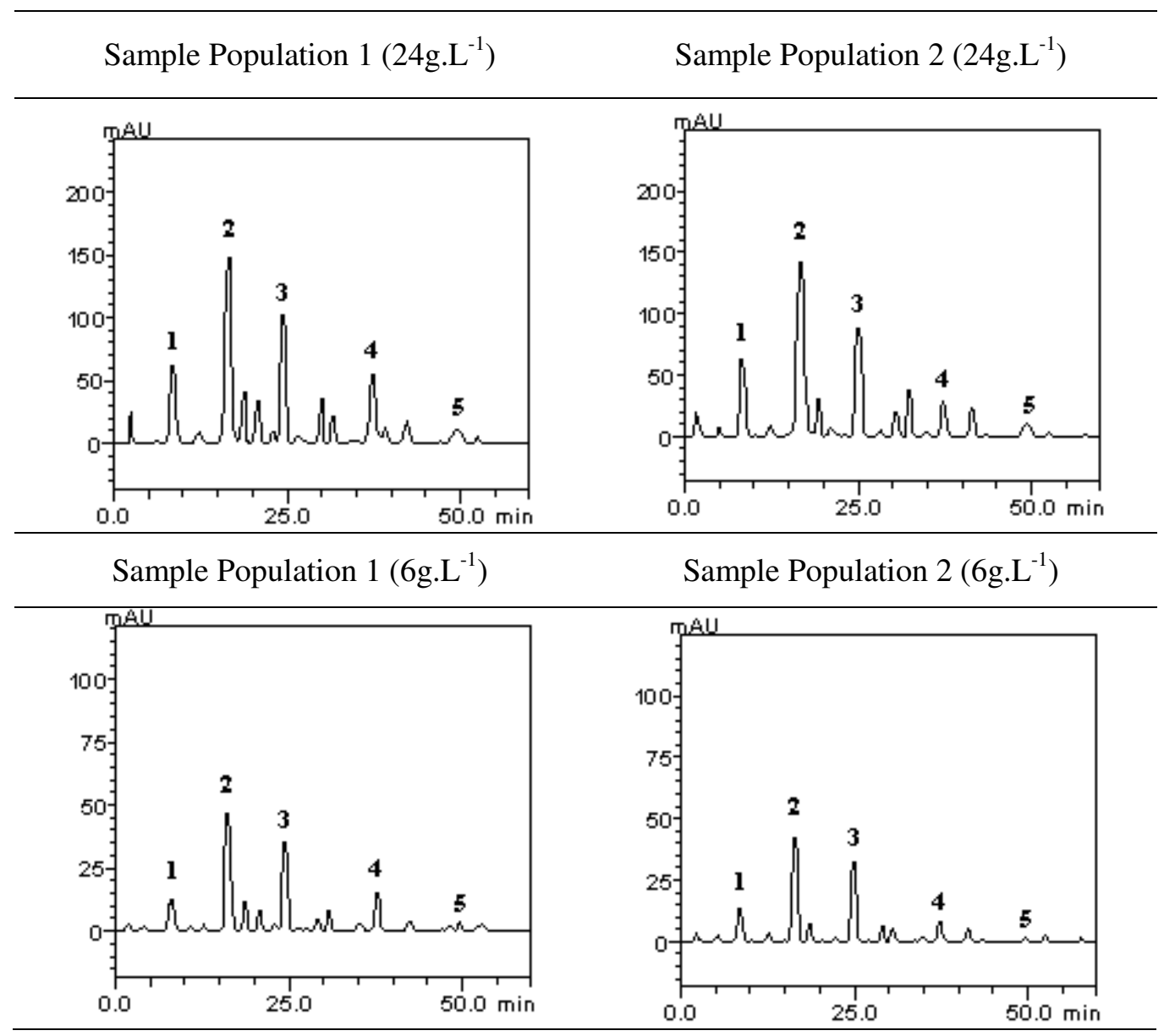

Figure 2. Representative high performance liquid chromatography profile of $C$. sinensis, detection UV was at 327nm. Gallic acid (peak 1), chlorogenic acid (peak 2), caffeic acid (peak 3), rutin (peak 4) and kaempferol (peak 5). Chromatographic conditions are described in the Methods section.

Table 3. Composition of phenolic and flavonoid compounds of $C$. sinensis.

\begin{tabular}{|c|c|c|c|c|}
\hline \multirow{3}{*}{ Compounds } & \multicolumn{4}{|c|}{ C. sinensis $\left(24 \mathrm{~g} . \mathrm{L}^{-1}\right)$} \\
\hline & \multicolumn{2}{|c|}{ Population 1 - SM } & \multicolumn{2}{|c|}{ Population 2 - Tupã } \\
\hline & $\mathrm{mg} / \mathrm{L}$ & $\%$ & $\mathrm{mg} / \mathrm{L}$ & $\%$ \\
\hline Gallic acid & $4.91 \pm 0.02^{\mathrm{a}}$ & 0.49 & $4.89 \pm 0.01^{\mathrm{a}}$ & 0.48 \\
\hline Chlorogenic acid & $11.86 \pm 0.03^{b}$ & 1.18 & $10.75 \pm 0.04^{b}$ & 1.07 \\
\hline Caffeic acid & $8.25 \pm 0.01^{c}$ & 0.82 & $6.63 \pm 0.06^{c}$ & 0.66 \\
\hline Rutin & $4.62 \pm 0.05^{\mathrm{a}}$ & 0.46 & $2.94 \pm 0.05^{\mathrm{d}}$ & 0.29 \\
\hline Kaempferol & $2.17 \pm 0.02^{\mathrm{d}}$ & 0.21 & $2.03 \pm 0.02^{\mathrm{d}}$ & 0.20 \\
\hline
\end{tabular}

Results are expessed in mean \pm standard deviation (SD) of three determinations. Columns followed by different letters differ by the Tukey test $(p<0.05)$.

Table 4. Composition of phenolic and flavonoid compounds of $C$. sinensis

\begin{tabular}{|c|c|c|c|c|}
\hline \multirow{3}{*}{ Compounds } & \multicolumn{4}{|c|}{ Citrus sinensis $\left(6 \mathrm{~g} . \mathrm{L}^{-1}\right)$} \\
\hline & \multicolumn{2}{|c|}{ Population 1-SM } & \multicolumn{2}{|c|}{ Population 2 - Tupã } \\
\hline & $\mathrm{mg} / \mathrm{L}$ & $\%$ & $\mathrm{mg} / \mathrm{L}$ & $\%$ \\
\hline Gallic acid & $1.36 \pm 0.01^{\mathrm{a}}$ & 0.13 & $1.26 \pm 0.03^{\mathrm{a}}$ & 0.12 \\
\hline Chlorogenic acid & $3.08 \pm 0.02^{b}$ & 0.30 & $2.73 \pm 0.04^{b}$ & 0.27 \\
\hline Caffeic acid & $2.15 \pm 0.02^{\mathrm{c}}$ & 0.21 & $1.81 \pm 0.01^{\mathrm{c}}$ & 0.18 \\
\hline Rutin & $1.10 \pm 0.03^{\mathrm{a}}$ & 0.11 & $0.73 \pm 0.03^{\mathrm{d}}$ & 0.07 \\
\hline Kaempferol & $0.54 \pm 0.01^{\mathrm{d}}$ & 0.05 & $0.39 \pm 0.02^{\mathrm{e}}$ & 0.03 \\
\hline
\end{tabular}

Results are expessed in mean \pm standard deviation (SD) of three determinations. Columns followed by different letters differ by the Tukey test $(p<0.05)$. 
The aqueous extracts of $C$. sinensis contain flavonoids and phenolic acids as principal components. These compounds can be responsible for inhibiting cell division and the appearance of chromosomal aberrations. Flavonoids have demonstrated to possess cytotoxic activity (SHI et al., 2001). The flavonoids of Humulus lupulus L. and Lonchocarpus spp. Kunth presented cytotoxic and antiproliferative activity on the cell cycle and cancer cells of the prostate (DELMULLE et al., 2006; BORGES-ARGÁEZ et al., 2007).

\section{CONCLUSION}

Through the results obtained in our study, it is possible to verify antiproliferative and genotoxic activity in the species studied, indicating that its use by the populations requires more care. However, more studies are necessary to more accurately assess the potential risks of the genotoxic agents present in aqueous extracts of $C$. sinensis. Already the HPLC analysis revealed that flavonoids (rutin and kaempferol) and phenolic acids (gallic acid, caffeic acid, and chlorogenic acid) are the principal components of $C$. sinensis.

\section{ACKNOWLEDGEMENTS}

The authors thank Conselho Nacional de Desenvolvimento Científico e Tecnológico (CNPq) and Fundação de Amparo à pesquisa do Rio Grande do Sul (FAPERGS/CAPES) for the financial support and granted fellowship.

RESUMO: A espécie Citrus sinensis (laranjeira) (L.) Osbeck é usada na medicina popular como infusão (chá) para o tratamento de irritações nervosas, insônia, espasmos, tosse convulsa, gripes e problemas gastrointestinais. $\mathrm{O}$ objetivo desse estudo foi avaliar o potencial antiproliferativo e genotóxico dos extratos aquosos de Citrus sinensis pelo teste de Allium cepa L., bem como determinar os componentes na mistura complexa (chá). Folhas de duas populações dessa espécie foram utilizadas no preparo das infusões em duas concentrações: $6 \mathrm{~g} . \mathrm{L}^{-1}$ e $24 \mathrm{~g} . \mathrm{L}^{-1}$, além de serem usados água destilada como controle negativo e glifosato $9,6 \%$ como controle positivo. Utilizaram-se seis grupos de quatro bulbos de A. cepa, cada grupo correspondendo a um dos tratamentos. Os bulbos foram enraizados em água destilada e então transferidos para os respectivos tratamentos onde permaneceram por 24 horas (os bulbos do controle negativo permaneceram em água destilada). As radículas foram coletadas, fixadas em etanol-ácido acético (3:1) por 24 horas e armazenadas em álcool 70\%. Foram analisadas 4,000 células por grupo de bulbos, e os índices mitóticos calculados submetidos à análise estatística pelo teste $\chi^{2}$. Os extratos aquosos de $C$. sinensis têm como componentes principais flavonoides e ácidos fenólicos. Os valores dos índices mitóticos diminuíram com o aumento das concentrações dos extratos, em relação ao controle em água. Os resultados indicaram que os extratos aquosos de laranjeira nas concentrações estudadas das duas populações possuem ação antiproliferativa e genotóxica sobre o ciclo celular de $A$. cepa.

PALAVRAS-CHAVE: Planta medicinal. Laranjeira. Cebola. Índices mitóticos. Mutagênico.

\section{REFERENCES}

AMORIM, M. F. D.; DINIZ, M. F. F. M.; ARAÚJO, M. S. T.; PITA, J. C. L. R.; DANTAS, J. G.; RAMALHO, J. A.; XAVIER, A. L.; PALOMARO, T. V.; JÚNIOR, N. L. B. The controvertible role of kava (Piper methysticum G. Foster) an anxiolytic herb, on toxic hepatitis. Revista Brasileira de Farmacognosia, Curitiba, v. 17, p. 448-454, 2007. http://dx.doi.org/10.1590/S0102-695X2007000300020

ANWAR, F.; NASEER, R.; BHANGER, M. I.; ASHRAF, S.; NAZ, T. F.; ALADEDUNYE, F. A. PhysicoChemical Characteristics of Citrus Seeds and Seed Oils from Pakistan. Journal of the American Oil Chemists' Society, Texas, v. 85, p. 321-330, 2008.

AYRES, M. BioEstat 5.3: Aplicações estatísticas nas areas das ciências biológicas e médicas. 5. Ed. Belém: Sociedade Civil Mamirauá, Brasília CNPq. 2007.

BARATA-SILVA, A. W.; MACEDO, R. L. G.; GOMES, J. E. Potencial de utilização de espécies arbóreas medicinais no Rio Grande do Sul. Revista Científica Eletrônica de Engenharia Florestal, Garça-SP, a. 3, n. 6, 2005. Disponível em: <www.revista.inf.br/florestal06/pages/artigos/artigo08.pdf>. Acesso em: 20 dez. 2013. 
BORGES-ARGÁEZ, R.; BALNBURY, L.; FLOWERS, A.; GIMÉNEZ-TURBA, A.; RUIZ, G.; WATERMAN, P. G.; PEÑA-RODRÍGUEZ, L. M. Cytotoxic and antiprotozoal activity of flavonoids from Lonchocarpus spp. Phytomedicine, Stuttgart, v. 14, p. 530-533, 2007. http://dx.doi.org/10.1016/j.phymed.2006.11.027

CABRERA, G. L.; RODRIGUEZ, D. M. G. Genotoxicity of soil from farmland irrigated with wastewater using three plant biossays. Mutation Research, Amsterdam, v. 426, p. 211-214, 1999. http://dx.doi.org/10.1016/S0027-5107(99)00070-6

CAMPAROTO, M. L.; TEIXEIRA, R. O.; MANTOVANI, M. S.; VICENTINI, V. E. P. Effects of Maytenus ilicifolia Mart. and Bauhinia candicans Benth infusions on onion root-tip and rat bone-marrow cells. Genetics and Molecular Biology, Ribeirão Preto, v. 25, p. 85-89, 2002. http://dx.doi.org/10.1590/S141547572002000100016

CARIBÉ, J.; CAMPOS, J. M. Plantas Que Ajudam o Homem. 5 ed. São Paulo: Pensamento, 1991. p. 89.

DALLA NORA, G.; PASTORI, T.; LAUGHINGHOUSE IV, H. D.; CANTO-DOROW, T. S.; TEDESCO, S. B. Antiproliferative and genotoxic effects of Mikania glomerata (Asteraceae). Biocell, Mendoza, v. 34, p. 85$101,2010$.

DELMULLE, L.; BELLAHCÈNE, A.; DHOOGE, W.; COMHAIRE, F.; ROELENS, F.; HUVAERE, K.; HEYERICK, A.; CASTRONOVO, V.; DE KEUKELEIRE, D. Anti-proliferative properties of prenylated flavonoids from hops (Humulus lupulus L.) in human prostate cancer cell lines. Phytomedicine, Stuttgart, v. 13, p. 732-734, 2006. http://dx.doi.org/10.1016/j.phymed.2006.01.001

FACHINETTO, J. M.; BAGATINI, M. D.; DURIGON, J.; SILVA, A. C. F.; TEDESCO, S. B. Efeito antiproliferativo das infusões de Achyrocline satureioides DC (Asteraceae) sobre o ciclo celular de Allium cepa. Revista Brasileira de Farmacognosia, Curitiba, v. 17, p. 49-54, 2007.

FACHINETTO, J. M.; TEDESCO, S. B. Atividade antiproliferativa e mutagênica dos extratos aquosos de Baccharis trimera (Less.) A. P. de Candolle e Baccharis articulata (Lam.) Pers. (Asteraceae) sobre o sistema teste de Allium cepa. Revista Brasileira de Plantas Medicinais, Botucatu, v. 11, p. 360-367, 2009.

FISKESJÖ, G. Allium Test II: Assesmente of chemical's genotoxic potential by recording aberrations in chromosomes and cell divisions in root tips of Allium cepa L. Environmental Toxicology and Water Quality, New York, v. 9, p. 235-241, 1994. http://dx.doi.org/10.1002/tox.2530090311

FRESCURA, V.D.; Análise do potencial antiproliferativo, genotóxico e antimutagênico das espécies Psichotria brachypoda (Müll. Arg.) Briton e Psychotria birotula Smith \& Downs (Rubiaceae). 2012. $73 \mathrm{f}$. Dissertação (Mestrado em Agrobiologia) - Universidade Federal de Santa Maria, Santa Maria, RS, 2012.

GUERRA, M.; SOUZA, M.J. Como observar cromossomos: Um guia de técnicas em citogenética vegetal, animal e humana. Ribeirão Preto: Funpec, 2002. 131 p.

JOLY, A. B. Botânica: introdução à taxonomia vegetal. 13 Ed. São Paulo: Nacional. 2002. p. 407.

KELEBEK, H.; SELLI, S.; CANBAS, A.; CABAROGLU, T. HPLC determination of organic acids, sugars, phenolic compositions and antioxidant capacity of orange juice and orange wine made from a Turkish cv. Kozan. Microchemical Journal, Amsterdam, v. 91, p. 187-192, 2009. http://dx.doi.org/10.1016/j.microc.2008.10.008

KNOLL, M. F.; SILVA, A. C. F.; DOROW, T. S. C.; TEDESCO, S. B. Effects of Pterocaulon polystachyum DC. (Asteraceae) on onion (Allium cepa) root-tip cells. Genetics and Molecular Biology, Ribeirão Preto, v. 29, p. 539-542, 2006. http://dx.doi.org/10.1590/S1415-47572006000300024 
LAGHARI, A. H.; MEMON, S.; NELOFAR, A.; KHAN, K. M.; YASMIN, A. Determination of free phenolics acids and antioxidant activity of methanolic extracts obtained from fruits and leaves of Chenopodium album. Food Chemistry, New York, v. 126, p. 1850-1855, 2011. http://dx.doi.org/10.1016/j.foodchem.2010.11.165

LANINI, J.; DUARTE-ALMEIDA, J. M.; NAPPO, S.; CARLINI, E. A. "O que vêm da terra não faz mal" relatos de problemas relacionados ao uso de plantas medicinais por raizeiros de Diadema/SP. Revista Brasileira de Farmacognosia, Curitiba, v. 19, p. 121-129, 2009. http://dx.doi.org/10.1590/S0102695X2009000100022

LEME, D. M.; MARIN-MORALES, M. A. Allium cepa test in environmental monitoring: a review on its application. Mutation Research, Amsterdam, v. 682, p. 71-81, 2009.

http://dx.doi.org/10.1016/j.mrrev.2009.06.002

SCHULTZ, A. Introdução a botânica sistemática. 4 ed. Porto Alegre: Universidade, 1984. v.2, p. 173.

SHI, Y. Q.; FUKAI, T.; SAKAGAMI, H.; CHANG, W. J.; YANG, P. Q.; WANG, F. P.; NOMURA, T. Cytotoxic flavonoids with isoprenoids groups from Morus mongolica. Journal of Natural Products, Columbus, v. 64, p. 181-188, 2001. http://dx.doi.org/10.1021/np000317c

SOUZA, L. F.; LAUGHINGHOUSE IV, H. D.; PASTORI, T.; TEDESCO, M.; KUHN, A. W.; CANTODOROW, T. S.; TEDESCO, S. B. Genotoxic potential of aqueous extracts of Artemisia verlotorum on the cell cycle of Allium cepa. International Journal of Environmental Studies, London, v. 67, p. 871-877, 2010. http://dx.doi.org/10.1080/00207233.2010.520457

TEIXEIRA, R. O.; CAMPAROTO, M. L.; MANTOVANI, M. S.; VICENTINI, V. E. P. Assessment of two medicinal plants, Psidium guajava L. and Achillea millefolium L. in in vivo assays. Genetics and Molecular Biology, Ribeirão Preto, v. 26, p. 551-555, 2003. http://dx.doi.org/10.1590/S1415-47572003000400021

VICENTINI, V. E. P.; CAMPAROTO, M. L.; TEIXEIRA, R. O.; MANTOVANI, M. S. Averrhoa carambola L., Syzygium cumini (L.) Skeels and Cissus sicyoides L.: medicinal herbal tea effects on vegetal and animal test systems. Acta Scientiarum, Maringá, v. 23, p. 593-598, 2001.

YARZA, O. Plantas que curam \& Plantas que matam. São Paulo: Hemus, v. 2. 2001. p. 125. 